\title{
Plant Diversity Increased Arthropod Diversity and Crop Yield in Traditional Agroforestry Systems but Has No Effect on Herbivory
}

\author{
Daniel K. N'Woueni ${ }^{1}$ and Orou G. Gaoue ${ }^{1,2,3, *(D)}$
}

Citation: N’Woueni, D.K.; Gaoue, O.G. Plant Diversity Increased Arthropod Diversity and Crop Yield in Traditional Agroforestry Systems but Has No Effect on Herbivory. Sustainability 2022, 14, 2942. https:// doi.org/10.3390/su14052942

Academic Editors: Georgios Koubouris and Michael S. Carolan

Received: 25 December 2021 Accepted: 23 February 2022 Published: 3 March 2022

Publisher's Note: MDPI stays neutral with regard to jurisdictional claims in published maps and institutional affiliations.

Copyright: (c) 2022 by the authors. Licensee MDPI, Basel, Switzerland. This article is an open access article distributed under the terms and conditions of the Creative Commons Attribution (CC BY) license (https:// creativecommons.org/licenses/by/ $4.0 /)$.
1 Faculty of Agronomy, University of Parakou, Parakou 01 BP 123, Benin; danielnwoueni@gmail.com 2 Department of Ecology Evolutionary Biology, University of Tennessee Knoxville, Knoxville, TN 37996, USA 3 Department of Geography, Environmental Management and Energy Studies, University of Johannesburg, Auckland Park Campus, Johannesburg 2006, South Africa

* Correspondence: ogaoue@utk.edu
Abstract: Improving agricultural production in response to the increasing food demand remains a major challenge in agroecology. The world has made significant efforts to meet this issue by developing several cultivation techniques, such as the use of chemical fertilizers and arable land conversion into agricultural land. However, most of these techniques have caused a significant loss of biodiversity and ecosystems services. Recent data suggest that biological conservation within and around agroforestry systems are potential solutions that can both reduce biodiversity loss and guarantee crop production. This logic is based on the hypothesis that increasing plant diversity in and around agricultural systems can limit the pest attack rate and increase crop yield. We tested this hypothesis using structural equation modeling on empirical data collected in agroforestry systems around the Pendjari biosphere reserve in West Africa. We measured crop diversity, crop yield, arthropod pest diversity, abundance, the rate of crop herbivory, and the diversity of plants in surrounding natural vegetation in 32 permanent plots. We estimated arthropod diversity and abundance using pitfall traps. We found a direct positive effect for plant diversity and a direct negative effect of arthropod herbivory on crop yield. The diversity of plants in surrounding natural vegetation had a direct positive effect on arthropod pest diversity but a marginal negative direct effect on the rate of crop herbivory. We found no significant direct or indirect effect for crop diversity. Our findings underline the important role of biodiversity conservation in agricultural production improvement. We suggest that the conservation of plant diversity around agroforestry systems may be an effective option to control herbivory damage. Its combination with other pest control techniques may further limit crop depredation and ensure the long-term conservation of wildlife.

Keywords: diversity in human modified landscape; agrobiodiversity; pest control; crop yield; theory of biotic resistance; agroecology

\section{Introduction}

Improving global agricultural productivity is a major concern in the current context of increasing food demand [1-3]. In recent decades, advanced agricultural practices focusing on increased crop productivity rather than increasing arable land led to the improvement of world food production. For example, the development of effective cropping techniques, including soil fertility management, agricultural intensification, crop rotation, and genetic selection contributed to increased world food production [4-7]. World production of cereals, oilseeds, fruits and vegetables has increased by $47 \%$ [8], with an overall yield increase of $25 \%$ on only a $7 \%$ increase in crop land [2]. However, the increase in world food production seems to overlap with non-food production.

Globally, $62 \%$ of the world crop production is used for human food, 35\% for livestock, and $3 \%$ for bioenergy, seeds, and other industrial products, with a remarkable disparity 
between regions $[9,10]$. Because most of the increase in world food production requires increasing land conversion and deforestation instead of agricultural intensification [11,12], the gain that is made on ensuring food security is accompanied with a significant loss of biodiversity [13-18]. An important sustainability debate has focused on how to mitigate the increasing demand of land for agricultural purposes and the opportunity to share vs. spare land to achieve both biodiversity conservation and sustainable use of these lands [19-24]. The rationale behind land-sparing is centered around the urgency to conserve biological diversity in the current context of increased extinction of species and rapid biodiversity loss. Thus, sparing lands to provide habitat refuge for vulnerable and endangered species is considered a valuable land-use form, as converting these lands into pasture or crop thereby erodes the fundamental basis for sustainable agriculture [24]. Land-sharing promotes ecosystem services by integrating several land-use forms on limited land with the goal of liberating other lands for biodiversity conservation [22]. Such intensification of agricultural land use focuses on promoting agrobiodiversity as a mitigating strategy.

Consequently, the role of remnant natural vegetation and plant diversity in agricultural systems in improving crop yield with limited chemical inputs has received increasing attention [25]. Plant diversity in agricultural systems provides functional diversity that can limit the spread of pathogens and pests and promote beneficial insects for efficient biological control and pollination services [26-30]. Sustainable production of food in poor or developing countries therefore requires diversified agro-ecosystems to control crop herbivory $[25,26,31]$. Despite the increasing human-mediated environmental filtering and loss of biodiversity, our understanding of the role of diversity in agroecological systems on human nutrition and health $[32,33]$ and on ecosystem services is still limited but increasing [34,35]. In addition, our understanding of how mixed farming affects crop yield is limited. However, previous studies have shown that plant diversity in natural ecosystems or agricultural systems can improve agricultural production [3,36-38] due to niche complementarity [39-41].

In this study, we tested the biotic resistance hypothesis that biodiversity mitigates damage caused by pests and increases productivity [33]. Specifically, we used structural equation modeling (SEM) to examine the relative roles of plant diversity in natural vegetation and in agroforestry systems on crop yield and how such effects are mediated by reduced crop herbivory. Structural equation modelling [42] is a powerful statistical tool that combines in a single causal network several predictor and response variables [43]. We hypothesized that plant diversity would increase the diversity of arthropod pests and indirectly decrease crop yield by increasing pest herbivory rates due to diverse arthropod communities. We hypothesized a stronger indirect effect of plant diversity than a direct effect on crop yield. We highlighted how the degree of connectivity between natural landscapes, which house a rich diversity and abundant insect community, and agricultural landscapes during the growing season can influence the productivity of agroforestry systems $[44,45]$.

\section{Materials and Methods}

\subsection{Study Area}

The Pendjari Biosphere Reserve covers $4661.4 \mathrm{~km}^{2}$ and is located in the northwest of Benin between $10^{\circ} 30^{\prime} \mathrm{N}-11^{\circ} 30^{\prime} \mathrm{N}$ and $0^{\circ} 50^{\prime}-2^{\circ} 00^{\prime} \mathrm{E}$. The annual rainfall ranges from 1000 to $1100 \mathrm{~mm}$, with an average annual temperature of $27^{\circ} \mathrm{C}\left(21-40^{\circ} \mathrm{C}\right)$ [46]. The rainy season lasts nearly five months, from mid-May to October, followed by a dry season from November to February. The Biosphere reserve is organized into three main zones: a core area or protected zone (The Pendjari National Park), a buffer zone, and a transition zone, where sustainable agriculture is permitted. The Pendjari Biosphere Reserve is dominated by woodland, tree, shrub, and grassy savannas. The most abundant plant species include Anogeissus leiocarpa, Combretum spp., Pterocarpus erinaceus, Acacia gourmaensis, Crossopteriyx febrifuga, Detarium microcarpa, Burkea africana, and Terminalia macroptera in the savanna. Parinari congensis and Pterocarpus santalinoides are the main plant species in riparian forests and 
Khaya senegalensis and Vitex chrysocarpa in gallery forests [47]. Wildlife is mainly dominated by Kob, Kobus kob (9.65 individuals $\left./ \mathrm{km}^{2}\right)$, and western buffaloes (5.91 individuals $/ \mathrm{km}^{2}$ ), with species such as the cheetah and the waterbuck rare in the reserve [48]. In the transition zone of the Biosphere reserve, farmers practice traditional agroforestry systems established on poorly developed tropical ferruginous and hydromorphic soils [49]. Plant communities in the transition zone are increasingly degraded by a rapidly growing population [50]. A population growth rate of $36.79 \%$ was recorded from 2000 to 2013.

The Pendjari hunting zone is bordered by two main roads (Tanguieta-Batia road, and the Tanguieta-Porga road), which serve as a clear border for the Biosphere reserve. Along the two main roads and inside the Pendjari hunting zone, local populations establish traditional agroforestry systems and are authorized to gather non-timber forest products within the first $5 \mathrm{~km}$ perpendicular to the roads [51]. Along the two roads, three main ethnic groups are established: the Berba, which accounts for $65 \%$ of the population along the northwestern side, and the Wama and Gourmantche, which account for $30 \%$ and are established along the northeastern side [52]. Farm extensions in the area occupied by the Wama-Gourmantche are constrained by the Atacora chain of mountains, which have unsuitable soil for agriculture. Traditional agroforestry systems in the region occupied by the Berba are more diversified than that of the Wama-Gourmantche [50].

\subsection{Measuring Plant, Arthropod Diversity, and Crop Yield}

To test the effects of wild (non-crop) plant and crop diversity on arthropod diversity, crop herbivory rate, and yield, we randomly sampled 32 traditional agroforestry systems and 8 surrounding natural habitats within $100 \mathrm{~m}$ from the edge of agroforestry systems. Within each agroforestry system or adjacent natural vegetation, we established a $30 \times 30 \mathrm{~m}$ plot to survey and record every plant species in the plot. Adult tree species with a diameter at breast height $(\mathrm{dbh}) \geq 5 \mathrm{~cm}$ were counted within each plot, and the species in lower vegetation layers $(\mathrm{dbh}<5 \mathrm{~cm}$ ), including herbs, were counted within five $5 \mathrm{~m} \times 5 \mathrm{~m}$ quadrats (one quadrat in the center and four in the corners of the plot). Plant diversity in agroforestry systems and adjacent vegetation was simply estimated as species richness.

Arthropods are both pests and beneficial components of agricultural systems [29,53-55]. As such, they can cause crop damage through herbivory but also serve as predators of insect herbivores, thereby providing beneficial services that can increase crop yield. It is estimated that $30-40 \%$ of crop yield is lost to pests [22]. Arthropod diversity and abundance can be influenced by neighboring vegetation $[55,56]$. We measured arthropod diversity and abundance, particularly the differences between functional groups, to investigate how arthropods can affect crop herbivory in traditional agroforestry systems. To measure arthropod abundance and diversity in soil and litter, we installed in each plot 36 pitfall traps, each filled with soapy water. These traps were spaced $5 \mathrm{~m}$ apart, and arthropods were collected $72 \mathrm{~h}$ after the traps were set in the morning and conserved in alcohol prior to species identification. A total of 1152 pitfall traps were used for the $3230 \times 30 \mathrm{~m}$ plots. Arthropod species were identified (Table 1) by the entomology laboratory at the University of Parakou (Parakou, Benin), and the number of individuals of each species was counted. For species that were not directly identified, a morphotype was attributed to each individual arthropod, according to their morphological aspects, for an in-depth species determination [57].

The rate of crop herbivory was measured as the percentage of crop leaves damaged by pests 8 weeks after the period of seed sowing in these farms. To estimate crop yield, we selected maize and sorghum because they represent the main food source for local population in the study area [58]. For each of the 32 agroforestry parklands, we visited the farmers at the end of the farming season during the crop harvesting period to estimate the quantity of maize and sorghum harvested. To estimate crop yield for maize and sorghum, farmers harvest corn cobs and sorghum panicle when they are dry. The corns were then shelled after 14 days and the grain removed from the cob. Because this process is performed using traditional machines, and each farmer paid CFA 500 ( USD 1) per $100 \mathrm{~kg}$, we were 
able to confirm the production based on the money that they paid. The sorghum panicle was also sun dried and winnowed to obtain the grains. The grains were put in a container and then weighed. We estimated the size of each of the 32 farms in hectares and used this to estimate the total weight for both corn and sorghum in kilogram per unit of hectare. This was used as our estimate of crop yield $[59,60]$.

Table 1. List of arthropods collected in pitfall traps in the agroforestry systems around the Pendjari Biosphere Reserve.

\begin{tabular}{|c|c|c|c|}
\hline Scientific Name & Family & Order & Trophic Group \\
\hline Oplostomus fuligineus & Scarabaeidae & Coleoptera & Omnivore \\
\hline Ctenicera destructor & Elateridae & Coleoptera & Herbivore \\
\hline Gryllus sp. & Grillidae & Orthoptera & Herbivore \\
\hline Smicronyx fulvus & Curculionidae & Coleoptera & Herbivore \\
\hline Zonocerus variegatus & Pyrgomorphideae & Orthoptera & Herbivore \\
\hline Toxoptera citricida & Aphidideae & Hemiptera & Herbivore \\
\hline Blaniulus guttulatus & Blaniulidae & Diplopoda & Herbivore (roots) \\
\hline Locusta migratoria & Acridideae & Orthoptera & Herbivore \\
\hline Cerotoma arcuata & Chrysomelidae & Coleoptera & Herbivore \\
\hline Stenaptinus insignis & Carabidae & Coleoptera & Herbivore \\
\hline Tachyura parvula & Carabidae & Coleoptera & Necrophage \\
\hline Polydesmus spp. & Polydesmidae & Diplopoda & Herbivore (roots) \\
\hline Caterpillar & Papilionidae & Lepidoptera & Herbivore \\
\hline Trichopluchia ni & Noctuidae & Lepidoptera & Herbivore \\
\hline Schistocerca gregaria & Acrididae & Orthoptera & Herbivore \\
\hline Ichnemonide & Ichneumonidae & Hymenoptera & Carnivore \\
\hline Dysdercus sp. & Pyrrhocoridae & Heteroptera & Nectarivore \\
\hline Vanessa cardui & Nymphalidae & Lepidoptera & Nectarivore \\
\hline Diabrotica virgifera & Chrysomelidae & Lepidoptera & Herbivore \\
\hline Blaniulus sp. & Blaniulidae & Myriapoda & Detritivore \\
\hline Schistocerca sp. & Acrididae & Orthoptera & Herbivore \\
\hline Helicoverpa armigera & Noctuidae & Lepidoptera & Herbivore \\
\hline Nymphalis polychloros (larvae) & Nymphalinae & Lepidoptera & Herbivore \\
\hline Geotrupes stercorarius & Geotrupidae & Coleoptera & Coprophage \\
\hline
\end{tabular}

\subsection{Statistical Analysis}

To test the effect of plant species richness (agroforestry systems and adjacent vegetation) on arthropod abundance, we used a generalized linear model with a negative binomial error structure, given the overdispersion of the arthropod abundance. We used the package boot [61] to conduct a bootstrap regression to test the effects of plant species richness on arthropod diversity (number of arthropods species). We used a simple linear model to test the effect of plant species richness (agroforestry system and adjacent vegetation) on crop yield. The central goal of this study was to elucidate the mechanistic role that plant diversity mediated by the effect on arthropods diversity and abundance and the resulting changes in crop herbivory rate in driving crop yield. For this purpose, we used the R package lavaan [62] to develop a structural equation model [43] to test the direct or indirect effects of plant diversity in agroforestry systems and adjacent vegetation on arthropod diversity and how this affected crop herbivory rate and crop yield. Structural equation models (SEM) are probabilistic models used to fit a single network of hypotheses to data that include several predictors and response variables [43]. SEM relies on causal assumptions between variables $[63,64]$. All statistical tests were performed in R 3.5.1.

\section{Results}

In the agroforestry systems, we identified 24 arthropod species, which belong to 16 families and 8 orders (Table 1). The arthropod community was dominated by coleoptera $(29 \%)$, lepidoptera $(25 \%)$, and orthoptera (21\%). Herbivores represented $71 \%$ of the species. Nearly $75 \%$ of these arthropods were plant pests and were mostly adults. The arthropods that were pests for crops represented $25 \%$ of the total richness and were either at the larval or adult stages (Table 1). The crops mainly included maize, sorghum, and in some villages, millet, and cowpea. The minimum crop yield was $0.5 \mathrm{~kg} / \mathrm{ha}$, and the maximum was $6235 \mathrm{~kg} / \mathrm{ha}$ (Table 2). In the agroforestry systems, we identified a total of eight species with Vittelaria paradoxa (70\%) as the most dominant species, followed by Parkia biglobosa $(20.8 \%)$ and Lannea acida (5\%). Other plant species in the agroforestry system included 
Anarcadium occidentale, Sterculia setigera, Acacia polyacantha, Prosopis africana, and Monotes kerstingii. In adjacent natural habitats, we identified 31 species, dominated similarly by Vittelaria paradoxa (30.5\%) and Parkia biglobosa (8.5\%), also including Combretum fragans (7.6\%), Terminalia avicennioides (6.8\%), Burkea africana (5.9\%), and Sterculia setigera (3.4\%).

Table 2. Main variables for the structural equation model, including mean, median, and standard deviation (SD) for arthropod number and diversity, crop yield, richness, total plant diversity, and herbivory rates. The number of sites sampled to estimate these variables is also indicated.

\begin{tabular}{ccccccc}
\hline & $\begin{array}{c}\text { Arthropod } \\
\text { Abundance }\end{array}$ & $\begin{array}{c}\text { Arthropod } \\
\text { Richness }\end{array}$ & $\begin{array}{c}\text { Crop } \\
\text { Yield } \\
\text { (kg/ha) }\end{array}$ & $\begin{array}{c}\text { Total Plant } \\
\text { Richness }\end{array}$ & $\begin{array}{c}\text { Crop } \\
\text { Richness }\end{array}$ & $\begin{array}{c}\text { Herbivory } \\
\text { Rate (\%) }\end{array}$ \\
\hline Minimum & 1 & 1 & 0.5 & 6 & 2 & 1.34 \\
Median & 9.5 & 4 & 550 & 11.5 & 3.5 & 2.96 \\
Mean & 13.2 & 4.7 & 828.9 & 10.8 & 3.7 & 3.02 \\
Maximum & 47 & 13 & 6250 & 14.0 & 6 & 4.52 \\
SD & 11.2 & 3.4 & 1155.9 & 2.5 & 1.03 & 0.97 \\
Sample size & 32 & 32 & 32 & 32 & 32 & 14 \\
\hline
\end{tabular}

Total plant diversity had significant effect on crop yield and arthropod diversity (Figure 1). Arthropod diversity increased non-linearly with arthropod abundance $(\beta=0.04 \pm 075$; Figure 2A) but slightly decreased with plant diversity in the surrounding natural vegetation ( $\beta=0.36 \pm 0.12 ; p=0.01$; Figure $2 \mathrm{~B}$ ). We found no significant effect of crop diversity in agroforestry systems on the rate of herbivory $(\beta=-0.06 \pm 0.16, p=0.71$; Figure $2 \mathrm{C})$ and on crop yield (Figure 1, Table 3 ), but total surrounding plant diversity tended to increase crop yield ( $\beta=4.21 \pm 1.78 ; p=0.02$, Figure 1$)$ without a direct effect on herbivory rates (Figure 1). Similarly, arthropod diversity did not affect herbivory rates (Figure 1) or crop yield $(\beta=-0.64 \pm 3.09, p=0.84$, Table 3 ). Surprisingly, crop diversity had no significant effect on arthropods diversity $(\beta=0.06 \pm 0.28 ; p=0.82$, Table 2$)$, crop herbivory rate $(\beta=-0.04 \pm 0.21, p=0.85)$, or yield $(\beta=-1.06 \pm 2.35, p=0.65$; Table 3, Figure 1$)$. However, crop herbivory tended to significantly decrease crop yield ( $\beta=-0.2 \pm 0.61$; Figures 1 and 2D).

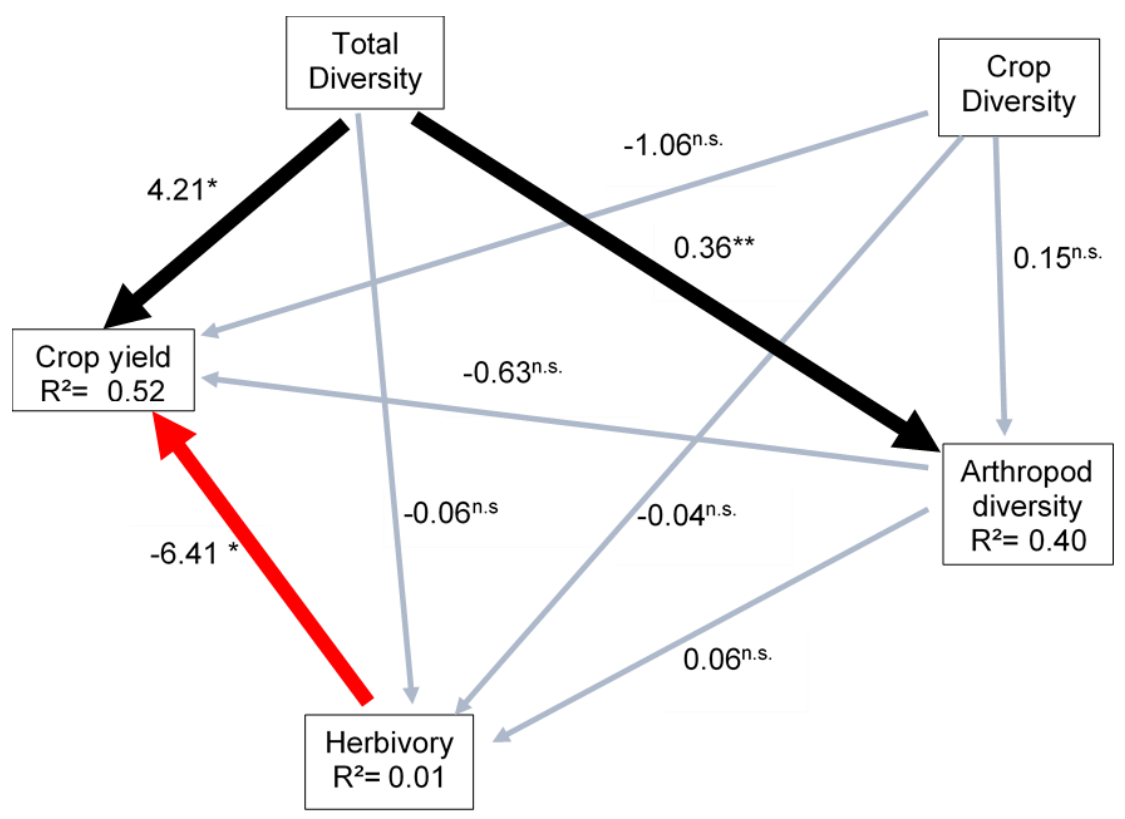

Figure 1. Structural equation model of the effects of plant diversity on crop yield, arthropod diversity and the negative effect of herbivory on crop yield in agroforestry systems. The thick black lines indicate positive relationships, the red line indicates negative relationships, and the gray lines non-significant relationships (n.s). ${ }^{*} p<0.05,{ }^{* *} p<0.01$. $\mathrm{R}^{2}$ is the proportion of variance explained. 
A
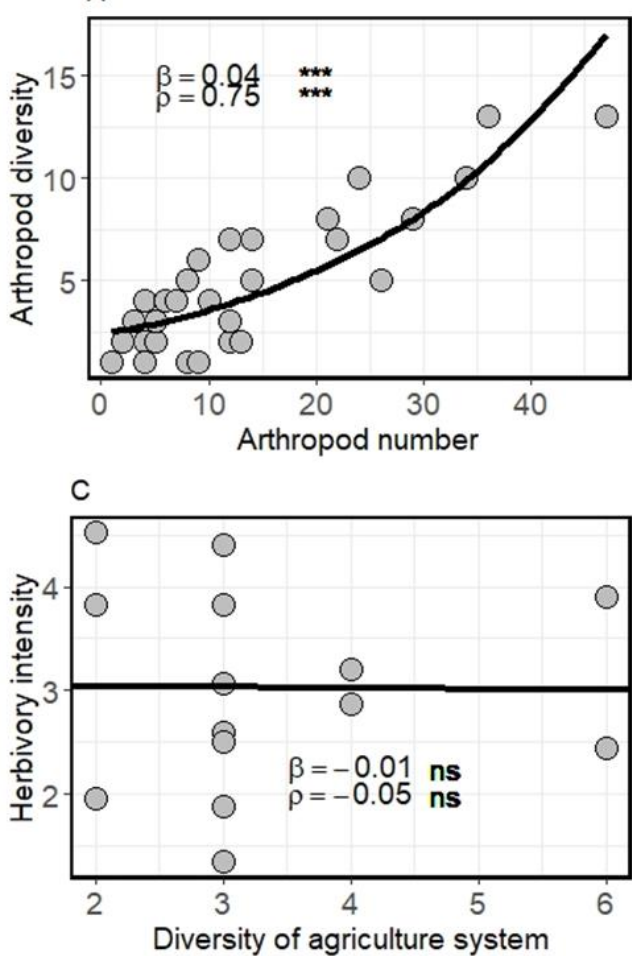

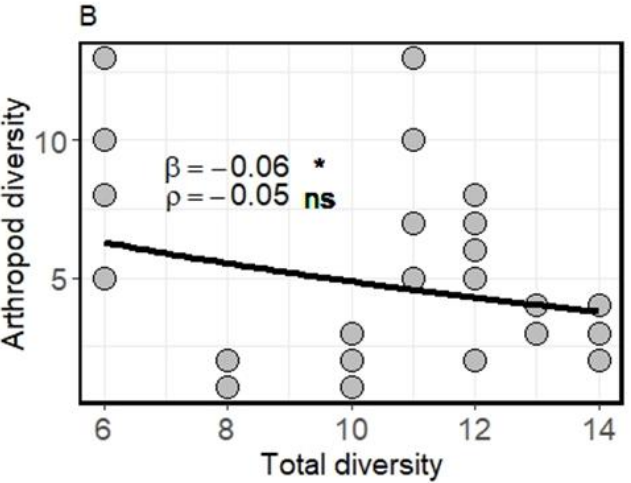

D

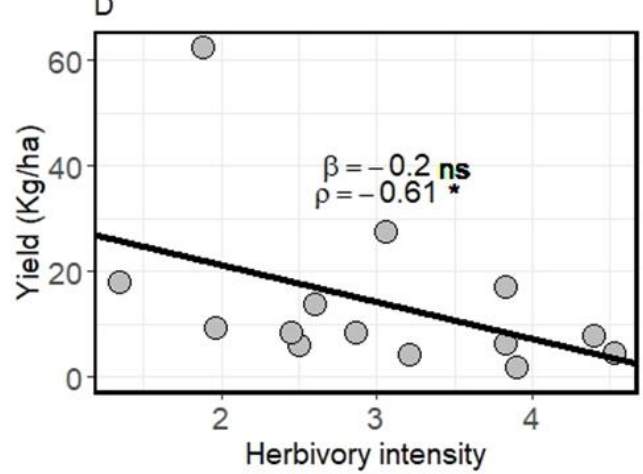

Figure 2. Effects of (A) arthropod abundance, (B) total diversity on arthropod diversity, effect of (C) crop diversity on crop herbivory intensity, and (D) the effect of herbivory intensity on crop yield. $\beta$ is the slope of the regression and $\rho$ is the Pearson correlation coefficient. Asterisks indicate $*<0.05$, *** $p<0.001$ and ns: non-significant.

Table 3. Path coefficients of structural equation model (SEM) between response and explanatory variables of the functional diversity of natural systems and agroforestry systems and agricultural yield. The column "Std.all" shows the standardized all-path coefficients, and "Std.lv" shows path coefficients with only latent variables coefficients standardized.

\begin{tabular}{|c|c|c|c|c|c|c|}
\hline Causal Relationships in the SEM & Estimate & SE & $\mathbf{z}$ & $p$ & Std.lv & Std.all \\
\hline Herbivory Arthropod diversity & 0.064 & 0.281 & 0.228 & 0.820 & 0.064 & 0.078 \\
\hline Herbivory Crop diversity & -0.039 & 0.213 & -0.184 & 0.854 & -0.039 & -0.052 \\
\hline Herbivory $\sim$ Total diversity & -0.059 & 0.162 & -0.366 & 0.714 & -0.059 & -0.130 \\
\hline Crop yield $\sim$ Herbivory & -6.407 & 2.937 & -2.181 & 0.029 & -6.407 & -0.402 \\
\hline Crop yield Arthropod diversity & -0.635 & 3.099 & -0.205 & 0.838 & -0.635 & -0.049 \\
\hline Crop yield $\sim$ Crop diversity & -1.063 & 2.348 & -0.453 & 0.651 & -1.063 & -0.088 \\
\hline Crop yield $\sim$ Total diversity & 4.210 & 1.784 & 2.360 & 0.018 & 4.210 & 0.540 \\
\hline Arthropod diversity $\sim$ Total diversity & 0.363 & 0.119 & 3.062 & 0.002 & 0.363 & 0.654 \\
\hline Arthropod diversity Crop diversity & 0.148 & 0.199 & 0.747 & 0.455 & 0.148 & 0.160 \\
\hline
\end{tabular}

\section{Discussion}

We documented how plant and crop diversity can mediate the impact of arthropod diversity, abundance, and subsequent herbivory on crop yield in traditional agroforestry systems in a West African biosphere reserve. We hypothesized that crop yield will be positively associated with plant diversity in natural vegetation surrounding the agroforestry systems. We found no significant effect of crop diversity, but we found a significant positive influence of plant diversity around agroforestry systems on crop yield. These results add to the growing evidence that crop yield can benefit from the conservation of a range of different tree and shrub species within and around farms [32,65]. Consistent with the theory of biotic resistance, which suggests that increasing plant diversity will reduce crop damage caused by pests, one can expect an increase in the productivity and crop yield of agroforestry systems with higher diversity [33]. The increase in crop yield observed here can also be explained by the border spillover effect, where farms benefit 
from the surrounding vegetation in terms of organic matter intake $[60,66,67]$. It may also result from the positive effects of microbial activity or ecosystem services efficiency. Our results revealed the presence of many decomposers belonging to Geotrupid family such as Geotrupes stercorarius, which are normally found in fresh dung, horse dung, and the droppings of different animals and beetles such as Oplostomus fuligineus (Table 1). Our results also highlight the importance of ecosystem services on agroecological systems.

One of the consequences of biological diversity is to maintain ecosystem services, including soil quality, pollination services, and pest control in agricultural systems [25]. We hypothesized that the positive effects of plant diversity on crop yield will be mediated by a negative direct effect on pest diversity and abundance, which is expected to cause increased crop herbivory rates. We found that plant diversity increased crop yield without reducing herbivory rate. However, arthropod pest diversity increased with diversity in surrounding natural vegetation, particularly with the predominance of Coleoptera and Lepidoptera larvae (Table 1). This contrasts with the prediction from the biotic resistance hypothesis [33] that plant diversity mitigates damage caused by pests. This result may be explained by the positive effect of plant diversity in surrounding habitats on positive ecological interactions such as crop pollination services due to pollinators' diversity and abundance in adjacent agroforestry systems $[68,69]$. Consistent with the associated resistance hypothesis, such diversity of neighbouring species could have mitigated herbivory damage by reducing the effect of specialized pests $[70,71]$. In addition, previous studies show that regional and agricultural biodiversity can decrease plant diseases and the proportion of graineating or fruit-eating animals in farms [44,72,73], which altogether can positively affect crop yield. The positive effect of plant diversity in surrounding habitats on arthropod diversity is perhaps due to the mitigating effect of a diverse surrounding habitat, which acts as a windbreak to limit agricultural pesticide spillover into agroforestry parklands and its negative effect on arthropod species [74,75]. In addition, arthropods encompass a wide range of species, including flying insect species, which can have positive and antagonistic interactions with crops. We did not record any flying arthropod species during our fieldwork, and this may explain the positive correlation between arthropod diversity or abundance and plant diversity in surrounding habitats [76,77].

Pest diversity can increase herbivory rate and reduce crop yield. However, in our study system, we found no significant direct or indirect effect of arthropod diversity on herbivory rate and on crop yield. Previous studies suggest that such lack of arthropod diversity effect may be due to pest specialization, environmental conditions, pest specificity, or the indirect effects of herbicide use in neighbouring fields [78-81]. The traditional agroforestry systems we studied in northern Benin were mixed systems composed of cereal crops, yam fields, cassava, sweet potato, and trees such as Vitellaria paradoxa and Parkia biglobosa [82]. These crop systems also coexist with large cotton farms that require heavy use of pesticides, which may affect the arthropod communities. This area was subjected to long-term agricultural activities that caused massive losses of forest land and modified forest management [50,52]. Crop pests can be affected by forest management and plant diversity around agricultural systems [83].

Our results show that pest diversity was not associated with herbivory rate. However, we found that herbivory rate had a significant negative direct effect on crop yield. This result adds to similar evidence provided by previous studies [84]. Cereals are annual crops that allocate more resources to growth and reproduction rather than to their survival [85]. Herbivory, by reducing crop growth, directly negatively impacts crop productivity [86] due to increasing biomass replacement costs and shifting biomass allocation away from reproduction [87]. The loss of leaves or the reduction in the leaf biomass due to pests could increase crop sensitivity to water stress that might reduce stomatal conductance necessary for photosynthesis [88]. 


\section{Conclusions}

In this study, we found that the diversity of natural vegetation surrounding agroforestry systems played a major role in crop yield improvement by directly increasing yield or by reducing the effect of herbivory. Fragments of natural habitats surrounding traditional agroforestry systems may be sufficient to provide essential ecosystems services for increasing agricultural yield. Our results suggest that plant species around and within traditional agroforestry systems need to be safeguarded to improve crop yield. Maintaining biodiversity around agroforestry systems must be prioritized in areas with strong demographic growth, limited by agricultural land availability, and a subsequently weak economy.

Author Contributions: D.K.N. and O.G.G. conceived the ideas of this study and designed the methodology. D.K.N. collected the data. O.G.G. and D.K.N. led the data analysis. D.K.N. wrote the draft of the paper with critical editorial contribution from O.G.G. All authors have read and agreed to the published version of the manuscript.

Funding: This research received no external funding, but the APC was funded by the University of Tennessee Knoxville's SARIF Open Publishing Support Fund and O.G.G. was supported by startup funds from UTK and NSF IRES grant \# 2107127.

Institutional Review Board Statement: Not applicable.

Informed Consent Statement: Not applicable.

Data Availability Statement: Data and code used in this study are available and will be published publicly.

Acknowledgments: We are grateful to Yacoubou Boni for field assistance, Oliver Dassou, M'Mouyohoun Kouagou, and Rodrigue Balagueman, and four anonymous reviewers for comments on an earlier version of this manuscript, and Ismail Moumouni, Nourou Yorou, Franck Hongbete and Armand Natta for discussion on this topic.

Conflicts of Interest: The authors declare no conflict of interest.

\section{References}

1. Godfray, H.C.J.; Beddington, J.R.; Crute, I.R.; Haddad, L.; Lawrence, D.; Muir, J.F.; Pretty, J.; Robinson, S.; Thomas, S.M.; Toulmin, C. Food Security: The Challenge of Feeding 9 Billion People. Science 2010, 327, 812-818. [CrossRef] [PubMed]

2. Foley, J.A.; Ramankutty, N.; Brauman, K.A.; Cassidy, E.S.; Gerber, J.S.; Johnston, M.; Mueller, N.D.; O'Connell, C.; Ray, D.K.; West, P.C.; et al. Solutions for a cultivated planet. Nature 2011, 478, 337-342. [CrossRef] [PubMed]

3. Thomas, M.B. Ecological approaches and the development of "truly integrated" pest management. Proc. Natl. Acad. Sci. USA 1999, 96, 5944-5951. [CrossRef] [PubMed]

4. National Research Council. Toward Sustainable Agricultural Systems in the 21st Century; The National Academies Press: Washington, DC, USA, 2010; ISBN 978-0-309-14896-2.

5. Wood, S.A. Nutritional Functional Trait Diversity of Crops in South-Eastern Senegal. J. Appl. Ecol. 2018, 55, 81-91. [CrossRef]

6. Rasmussen, L.V.; Coolsaet, B.; Martin, A.; Mertz, O.; Pascual, U.; Corbera, E.; Dawson, N.; Fisher, J.A.; Franks, P.; Ryan, C.M. Social-ecological outcomes of agricultural intensification. Nat. Sustain. 2018, 1, 275-282. [CrossRef]

7. Jayne, T.; Snapp, S.; Place, F.; Sitko, N. Sustainable agricultural intensification in an era of rural transformation in Africa. Glob. Food Secur. 2019, 20, 105-113. [CrossRef]

8. FAO. FAOSTAT Database of the Food and Agricultural Organization (FAO) of the United Nations; FAO: Rome, Italy, 2011.

9. Monfreda, C.; Ramankutty, N.; Foley, J.A. Farming the planet: 2. Geographic distribution of crop areas, yields, physiological types, and net primary production in the year 2000. Glob. Biogeochem. Cycles 2008, 22. [CrossRef]

10. Ramankutty, N.; Evan, A.T.; Monfreda, C.; Foley, J.A. Farming the planet: 1. Geographic distribution of global agricultural lands in the year 2000. Glob. Biogeochem. Cycles 2008, 22. [CrossRef]

11. Asner, G.P.; Powell, G.V.N.; Mascaro, J.; Knapp, D.E.; Clark, J.K.; Jacobson, J.; Kennedy-Bowdoin, T.; Balaji, A.; Paez-Acosta, G.; Victoria, E.; et al. High-Resolution Forest Carbon Stocks and Emissions in the Amazon. Proc. Natl. Acad. Sci. USA 2010, 1-5. [CrossRef]

12. Gibbs, H.K.; Ruesch, A.S.; Achard, F.; Clayton, M.K.; Holmgren, P.; Ramankutty, N.; Foley, J.A. Tropical Forests Were the Primary Sources of New Agricultural Land in the 1980s and 1990s. Proc. Natl. Acad. Sci. USA 2010, 107, 16732-16737. [CrossRef] [PubMed]

13. Chamorro, L.; Masalles, R.M.; Sans, F.X. Arable weed decline in Northeast Spain: Does organic farming recover functional biodiversity? Agric. Ecosyst. Environ. 2016, 223, 1-9. [CrossRef] 
14. Hole, D.G.; Perkins, A.J.; Wilson, J.; Alexander, I.H.; Grice, P.V.; Evans, A.D. Does organic farming benefit biodiversity? Biol. Conserv. 2005, 122, 113-130. [CrossRef]

15. Humbert, J.-Y.; Dwyer, J.; Andrey, A.; Arlettaz, R. Impacts of nitrogen addition on plant biodiversity in mountain grasslands depend on dose, application duration and climate: A systematic review. Glob. Change Biol. 2015, 22, 110-120. [CrossRef]

16. Melts, I.; Lanno, K.; Sammul, M.; Uchida, K.; Heinsoo, K.K.T. Toward a mechanistic understanding of the effects of nitrogen and phosphorus additions on grassland diversity. J. Appl. Ecol. 2018, 32, 65-72.

17. Puig-Montserrat, X.; Stefanescu, C.; Torre, I.; Palet, J.; Fàbregas, E.; Dantart, J.; Arrizabalaga, A.; Flaquer, C. Effects of organic and conventional crop management on vineyard biodiversity. Agric. Ecosyst. Environ. 2017, 243, 19-26. [CrossRef]

18. Wilson, J.D.; Morris, A.J.; Arroyo, B.E.; Clark, S.C.; Bradbury, R.B. A review of the abundance and diversity of invertebrate and plant foods of granivorous birds in northern Europe in relation to agricultural change. Agric. Ecosyst. Environ. 1999, 75, 13-30. [CrossRef]

19. Zimmerer, K.S. The compatibility of agricultural intensification in a global hotspot of smallholder agrobiodiversity (Bolivia). Proc. Natl. Acad. Sci. USA 2013, 110, 2769-2774. [CrossRef]

20. Mikos, V.; Pulleman, M. European Policy Review: Functional agrobiodiversity supporting sustainable agriculture. J. Nat. Conserv. 2014, 22, 193-194. [CrossRef]

21. Mertz, O.; Mertens, C.F. Land Sparing and Land Sharing Policies in Developing Countries—Drivers and Linkages to Scientific Debates. World Dev. 2017, 98, 523-535. [CrossRef]

22. Grass, I.; Loos, J.; Baensch, S.; Batáry, P.; Librán-Embid, F.; Ficiciyan, A.; Klaus, F.; Riechers, M.; Rosa, J.; Tiede, J.; et al. Landsharing/-sparing connectivity landscapes for ecosystem services and biodiversity conservation. People Nat. 2019, 1, $262-272$. [CrossRef]

23. Latini, A.O.; Silva, D.P.; Souza, F.M.L.; Ferreira, M.C.; de Moura, M.S.; Suarez, N.F. Reconciling coffee productivity and natural vegetation conservation in an agroecosystem landscape in Brazil. J. Nat. Conserv. 2020, 57, 125902. [CrossRef]

24. Carney, J.A. Subsistence in the Plantationocene: Dooryard gardens, agrobiodiversity, and the subaltern economies of slavery. J. Peasant. Stud. 2020, 48, 1075-1099. [CrossRef]

25. Kremen, C.; Miles, A. Ecosystem Services in Biologically Diversified versus Conventional Farming Systems: Benefits, Externalities, and Trade-Offs. Ecol. Soc. 2012, 17, 40. [CrossRef]

26. Finckh, M.R.; Gacek, E.S.; Goyeau, H.; Lannou, C.; Mundt, C.C.; Munk, L.; Merz, U.; Nadziak, J.; Newton, A.; De Vallavieille-Pope, C.; et al. Cereal variety and species mixtures in practice, with emphasis on disease resistance. Science 2000, 20, 813-837. [CrossRef]

27. Pacheco, R.; Vasconcelos, H.L.; Groc, S.; Camacho, G.P.; Frizzo, T.L.M. The importance of remnants of natural vegetation for maintaining ant diversity in Brazilian agricultural landscapes. Biodivers. Conserv. 2013, 22, 983-997. [CrossRef]

28. Theron, K.J.; Gaigher, R.; Pryke, J.S.; Samways, M.J. Abandoned fields and high plant diversity support high spider diversity within an agricultural mosaic in a biodiversity hotspot. Biodivers. Conserv. 2020, 29, 3757-3782. [CrossRef]

29. Arnold, S.E.J.; Elisante, F.; Mkenda, P.A.; Tembo, Y.L.B.; Ndakidemi, P.A.; Gurr, G.M.; Darbyshire, I.A.; Belmain, S.R.; Stevenson, P.C. Beneficial insects are associated with botanically rich margins with trees on small farms. Sci. Rep. 2021, 11, 1-11. [CrossRef]

30. Galloway, A.D.; Seymour, C.L.; Gaigher, R.; Pryke, J.S. Organic farming promotes arthropod predators, but this depends on neighbouring patches of natural vegetation. Agric. Ecosyst. Environ. 2021, 310, 107295. [CrossRef]

31. Letourneau, D.K.; Armbrecht, I.; Rivera, B.S.; Lerma, J.M.; Carmona, E.J.; Daza, M.C.; Trujillo, A.R.; Escobar, S.; Riviera, L.; Galindo, V.; et al. Does plant diversity benefit agroecosystems? A synthetic review. Ecol. Appl. 2011, 21, 9-21. [CrossRef] [PubMed]

32. Carvalheiro, L.G.; Veldtman, R.; Shenkute, A.G.; Tesfay, G.B.; Pirk, C.; Donaldson, J.; Nicolson, S. Natural and within-farmland biodiversity enhances crop productivity. Ecol. Lett. 2011, 14, 251-259. [CrossRef]

33. Guyot, V.; Castagneyrol, B.; Vialatte, A.; Deconchat, M.; Jactel, H. Tree diversity reduces pest damage in mature forests across Europe. Biol. Lett. 2016, 12, 20151037. [CrossRef]

34. Hajjar, R.; Jarvis, D.I.; Gemmill-Herren, B. The utility of crop genetic diversity in maintaining ecosystem services. Agric. Ecosyst. Environ. 2008, 123, 261-270. [CrossRef]

35. Mundt, C.C. Use of multiline cultivars and cultivar mixtures for disease management. Annu. Rev. Phytopathol. 2002, 40, 381-410. [CrossRef]

36. Ewel, J.J. Natural systems as models for the design of sustainable systems of land use. Agrofor. Syst. 1999, 45, 1-21. [CrossRef]

37. Jackson, W. Natural systems agriculture: A truly radical alternative. Agric. Ecosyst. Environ. 2002, 88, 111-117. [CrossRef]

38. Lewis, W.J.; van Lenteren, J.C.; Phatak, S.C.; Tumlinson, J.H. A total system approach to sustainable pest management. Proc. Natl. Acad. Sci. USA 1997, 94, 12243-12248. [CrossRef]

39. Kardol, P.; Fanin, N.; Wardle, D. Long-term effects of species loss on community properties across contrasting ecosystems. Nature 2018, 557, 710-713. [CrossRef] [PubMed]

40. SSpehn, E.M.; Hector, A.; Joshi, J.; Scherer-Lorenzen, M.; Schmid, B.; Bazeley-White, E.; Beierkuhnlein, C.; Caldeira, M.C.; Diemer, M.; Dimitrakopoulos, P.G.; et al. Ecosystem effects of biodiversity manipulations in european grasslands. Ecol. Monogr. 2005, 75, 37-63. [CrossRef]

41. Tilman, D.; Reich, P.B.; Knops, J.; Mielke, T.; Wedin, D.; Lehman, C. Diversity and Productivity in a Long-Term Grassland Experiment. Science 2001, 294, 843-845. [CrossRef] [PubMed] 
42. Shipley, B. Cause and Correlation in Biology: A User's Guide to Path Analysis, Structural Equations and Causal Inference; Cambridge University Press: Cambridge, UK, 2002.

43. Grace, J.B. Structural Equation Modeling and Natural Systems; Cambridge University Press: Cambridge, UK, 2006. [CrossRef]

44. Boetzl, F.A.; Krimmer, E.; Krauss, J.; Steffan-Dewenter, I. Agri-environmental schemes promote ground-dwelling predators in adjacent oilseed rape fields: Diversity, species traits and distance-decay functions. J. Appl. Ecol. 2018, 56, 10-20. [CrossRef]

45. Fischer, J.; Lindenmayer, D.B. Beyond Fragmentation: The Continuum Model for Fauna Research and Conservation in HumanModified Landscapes. Oikos 2006, 112, 473-480. [CrossRef]

46. ASECNA. Données Climatiques, Station de Natitingou, Bénin; ASECNA: Cotonou, Benin, 2010.

47. Houehanou, T.D.; Assede, E.P.S.; Habiyaremye, F.M.; Sogbohossou, E.A.; Kouton, M.; Agbani, P.; Yaoitcha, A.S.; Gbeffe, A.K.; Houinato, M.R.B. La Réserve de La Biosphère de La Pendjari (Bénin) Guide et Lexique Pour Le Suivi Des Parcours Naturels: Habitats, Faune et Flore; Institut Royal des Sciences Naturelles de Belgique (IRSNB): Bruxelle, Belgique, 2017.

48. Nago, A.G.S.; Amahowe, I.; Zannou, O.; Houessou, L.; Ahononga, F.; N’Séra, P.; Sinsin, B.; Kouton, M.; Kidjo, F.; Sahilou, S. Diversité, abondance et densité des populations de faune dans la Réserve de Biosphère de la Pendjari (Nord Bénin). Ann. UP Série Sci. Nat. Agron. 2016, 6, 10-25.

49. Faure, P.; Volkoff, B. Some Factors Affecting Regional Differentiation of the Soils in the Republic of Benin (West Africa). Catena 1998, 32, 281-306. [CrossRef]

50. M’Woueni, D.; Gaoue, O.G.; Balagueman, R.O.; Biaou, H.S.S.; Natta, A.K. Road mediated spatio-temporal tree decline in traditional agroforests in an African biosphere reserve. Glob. Ecol. Conserv. 2019, 20, e00796. [CrossRef]

51. Téhou, A.C.; Amahowé, O.I.; Mensah, G.A. Importance des aires protégées du complexe des parcs du W, d'Arly et de la Pendjari pour les communautés riveraines et le grand public en République du Bénin. Ann. Sci. Agron. 2012, 16, $235-249$.

52. Gaoue, O.G. Determinant Factors for the Integrated Management of Pendjari Hunting Reserve Northem Benin. Engineer Thesis, University of Abomey-Calavi, Abomey-Calavi, Benin, 2000.

53. Landis, D.A.; Wratten, S.D.; Gurr, G.M. Habitat Management to Conserve Natural Enemies of Arthropod Pests in Agriculture. Annu. Rev. Entomol. 2000, 45, 175-201. [CrossRef] [PubMed]

54. Lundin, O.; Ward, K.L.; Williams, N.M. Identifying native plants for coordinated habitat management of arthropod pollinators, herbivores and natural enemies. J. Appl. Ecol. 2019, 56, 665-676. [CrossRef]

55. Arnold, J.E.; Egerer, M.; Daane, K.M. Local and Landscape Effects to Biological Controls in Urban Agriculture-A Review. Insects 2019, 10, 215. [CrossRef]

56. Egerer, M.; Liere, H.; Lucatero, A.; Philpott, S.M. Plant Damage in Urban Agroecosystems Varies with Local and Landscape Factors. Ecosphere 2020, 11, e03074. [CrossRef]

57. Barratt, B.I.P.; Derraik, J.G.B.; Rufaut, C.G.; Goodman, A.J.; Dickinson, K.J.M. Morphospecies as a substitute for Coleoptera species identification, and the value of experience in improving accuracy. J. R. Soc. New Zealand 2003, 33, 583-590. [CrossRef]

58. Biaou, H.S.S.; Natta, A.; Dicko, A. Typologie des systèmes agroforestiers et leurs impacts sur la satisfaction des besoins des populations rurales au Bénin. Bull. Rech. Agron. Bénin 2016, 43-56. Available online: ://www.slire.net/download/2371 /article_5complet_brab_n_sp_cial_esr_d_cembre_2016_biaou_et_al_typologie_des_syst_mes_agroforestiers.pdf (accessed on 24 December 2021).

59. Guillou, M.; Rogel-Gaillard, C. Agricultures et biodiversité: Des futurs liés. Ann. Mines Responsab. Environ. 2012, 68, 44-52. [CrossRef]

60. Traore, M.; Nacro, H.; Doamba, W.; Tabo, R.; Nikiema, A. Effets de doses variées du tourteau de Jatropha curcas sur la productivité du mil (variété HKP) en condition pluviale en Afrique de l'Ouest. Tropicultura 2015, 33, 19-25.

61. Canty, A.J. Resampling Methods in $\{R\}$ : The boot Package. R News 2002, 2, 2-7.

62. Rosseel, Y. Iavaan: An R package for structural equation modeling. J. Stat. Soft. 2012, 48, 1-36. [CrossRef]

63. Bollen, K.A.; Pearl, J. Eight Myths About Causality and Structural Equation Models. In Handbook of Causal Analysis for Social Research; Springer: Cham, Switzerland, 2013; pp. 301-328. [CrossRef]

64. Grace, J.B.; Irvine, K.M. Scientist's guide to developing explanatory statistical models using causal analysis principles. Ecology 2019, 101, e02962. [CrossRef] [PubMed]

65. Delaney, A.; Dembele, A.; Nombré, I.; Lirasse, F.G.; Marshall, E.; Nana, A.; Stout, J.C.; Vickery, J.; Tayleur, C. Local-scale tree and shrub diversity improves pollination services to shea trees in tropical West African parklands. J. Appl. Ecol. 2020, 57, 1504-1513. [CrossRef]

66. Kearns, C.A.; Inouye, D.W.; Waser, N.M. Endangered Mutualisms: The Conservation of Plant-Pollinator Interactions. Annu. Rev. Ecol. Syst. 1998, 29, 83-112. [CrossRef]

67. Song, B.Z.; Wu, H.Y.; Kong, Y.; Zhang, J.; Du, Y.L.; Hu, J.H.; Yao, Y.C. Effects of intercropping with aromatic plants on the diversity and structure of an arthropod community in a pear orchard. BioControl 2010, 55, 741-751. [CrossRef]

68. Balvanera, P.; Pfisterer, A.B.; Buchmann, N.; He, J.-S.; Nakashizuka, T.; Raffaelli, D.; Schmid, B. Quantifying the Evidence for Biodiversity Effects on Ecosystem Functioning and Services. Ecol. Lett. 2006, 9, 1146-1156. [CrossRef]

69. Gamfeldt, L.; Snäll, T.; Bagchi, R.; Jonsson, M.; Gustafsson, L.; Kjellander, P.; Ruiz-Jaen, M.C.; Fröberg, M.; Stendahl, J.; Philipson, C.D.; et al. Higher Levels of Multiple Ecosystem Services Are Found in Forests with More Tree Species. Nat. Commun. 2013, 4 1340. [CrossRef] 
70. Plath, M.; Dorn, S.; Riedel, J.; Barrios, H.; Mody, K. Associational Resistance and Associational Susceptibility: Specialist Herbivores Show Contrasting Responses to Tree Stand Diversification. Oecologia 2012, 169, 477-487. [CrossRef] [PubMed]

71. Sholes, O.D.V. Effects of Associational Resistance and Host Density on Woodland Insect Herbivores. J. Anim. Ecol. 2008, 77, 16-23. [CrossRef] [PubMed]

72. Lin, B.B. Resilience in Agriculture through Crop Diversification: Adaptive Management for Environmental Change. BioScience 2011, 61, 183-193. [CrossRef]

73. Geoff, M.G.; Stephen, D.; Wratten, J.M.L. Multi-function agricultural biodiversity: Pest management and other benefits. Basic Appl. Ecol. 2003, 4, 107-116.

74. Morales, M.B.; Winqvist, C.; Geiger, F.; Bengtsson, J.; Berendse, F.; Weisser, W.; Emmerson, M.; Ceryngier, P.; Liira, J.; Tscharntke, T.; et al. Persistent negative effects of pesticides on biodiversity and biological control potential on European farmland. Basic Appl. Ecol. 2010, 11, 97-105. [CrossRef]

75. Nicholls, C.I.; Altieri, M.A. Plant Biodiversity Enhances Bees and Other Insect Pollinators in Agroecosystems. A Review. Agron. Sustain. Dev. 2013, 33, 257-274. [CrossRef]

76. Randlkofer, B.; Obermaier, E.; Hilker, M.; Meiners, T. Vegetation complexity-The influence of plant species diversity and plant structures on plant chemical complexity and arthropods. Basic Appl. Ecol. 2010, 11, 383-395. [CrossRef]

77. Perner, J.; Wytrykush, C.; Kahmen, A.; Buchmann, N.; Egerer, I.; Creutzburg, S.; Odat, N.; Audorff, V.; Weisser, W. Effects of Plant Diversity, Plant Productivity and Habitat Parameters on Arthropod Abundance in Montane European Grasslands. Ecography 2005, 28, 429-442. [CrossRef]

78. Bebber, D.P.; Ramotowski, M.A.T.; Gurr, S.J. Crop pests and pathogens move polewards in a warming world. Nat. Clim. Change 2013, 3, 985-988. [CrossRef]

79. Cilas, C.; Babin, R.; Avelino, J. Tropical Crop Pests and Diseases in a Climate Change Setting-A Few Examples. In Climate Change and Agriculture Worldwide; Springer: Cham, Switzerland, 2016; pp. 73-82. [CrossRef]

80. Kraus, E.C.; Stout, M.J. Direct and Indirect Effects of Herbicides on Insect Herbivores in Rice, Oryza sativa. Sci. Rep. 2019, 9, 6998. [CrossRef] [PubMed]

81. Kughur, P.G. The Effects of Herbicides on Crop Production and Environment in Makurdi Local. J. Sustain. Develop. Africa 2012, 14, 206-216.

82. Harvey, R. Gros plan sur les parcs agroforestiers. Sahel Agroforesterie 2008, 11-12, 1-16.

83. Gallé, R.; Happe, A.; Baillod, A.B.; Tscharntke, T.; Batáry, P. Landscape configuration, organic management, and within-field position drive functional diversity of spiders and carabids. J. Appl. Ecol. 2018, 56, 63-72. [CrossRef]

84. Stephenson, A.G. Fruit Set, Herbivory, Fruit Reduction, and the Fruiting Strategy of Catalpa Speciosa (Bignoniaceae). Ecology 1980, 61,57-64. [CrossRef]

85. Kozłowski, J. Optimal Allocation of Resources to Growth and Reproduction: Implications for Age and Size at Maturity. Trends Ecol. Evol. 1992, 7, 15-19. [CrossRef]

86. Marquis, R.J. Leaf Herbivores Decrease Fitness of a Tropical Plant. Science 1984, 226, 537-539. [CrossRef]

87. Bazzaz, F.A.; Chiariello, N.R.; Coley, P.D.; Pitelka, L.F. Allocating Resources to Reproduction and Defense. BioScience 1987, 37, 58-67. [CrossRef]

88. Tang, J.Y.; Zielinski, R.E.; Zangerl, A.R.; Crofts, A.R.; Berenbaum, M.R.; Delucia, E.H. The Differential Effects of Herbivory by First and Fourth Instars of Trichoplusia Ni (Lepidoptera: Noctuidae) on Photosynthesis in Arabidopsis Thaliana. J. Exp. Bot. 2006, 57, 527-536. [CrossRef] [PubMed] 